\title{
大分県内の飲用温泉水に関する細菌学的検討
}

\author{
㴊 祐 一・緒方喜久代・成 松 浩 志・阿部 義昭 \\ 樋 田 俊 英・帆足喜久雄・牧野芳大 \\ （大分県衛生環境研究センター） \\ （受付 平成 10 年 12 月 16 日） \\ （受理 平成 11 年 2 月 3 日）
}

\section{Bacteriological Studies on the Drinking Hot Spring Waters in Oita Prefecture}

\author{
Yuichi Fuchi, Kikuyo Ogata, Hiroshi Narimatsu, Yoshiaki Abe, \\ Toshihide Hida, Kikuo Hoashi and Yoshihiro Makino \\ (Oita Prefectural Institute of Health and Environment, 2-51 Hogawaradai, Oita 870-0948)
}

Key words: Hot spring, Drinking water, Standard plate count, Coliforms, Escherichia coli

\section{緒言}

我が国の温泉水は一般に含有成分が希薄なため飲用の 効果は強くないと考えられ, 温泉療養は浴用を主体に行 われてきた。最近になって薬物療法の補助療法としての 医治利用に加え，近年の温泉ブームや自然食嗜好の広が りで飲用自体を目的とした利用も注目されるようにな り, 全国的に飲用温泉 (以下, 飲用泉) は年々増加して きている ${ }^{9)}$.

一方, 温泉水の飲用には衛生面での安全確保が不可欠 であることから, 1989 年 12 月に環境庁は温泉利用基準 を一部改正 ${ }^{2)} し て$ 従来の化学成分の規制に加え，年 1 回 の細菌学的検查を義務付けた．温泉水は水道水之異なり 消毒せずにそのまま飲用されるため，二次的な污染によ る感染症や食中毒を起こす可能性も考えられる．実際 に, 浴用温泉水の誤燕により感染したレジオネラ肺炎患 者の症例が報告4) されており，その後の調查で全国 17 温泉の浴槽水からレジオネラ属菌が検出されてい る ${ }^{13)}$. しかし, 飲用泉の衛生実態については, 林ら ${ }^{11}$ が飲 用利用施設 21 力所を調べた報告があるだけで，そのほ かには飲用利用でない鉱泉水を調查した世取山ら ${ }^{11,12)}$, 坂根ら ${ }^{10)}$ の報告が散見される程度である。

今回, 著者らは飲用泉としての許可申請に際して採水 された大分県内の温泉水を用いて, 細菌学的検査を中心 に飲用泉の衛生状況を調查したので，その結果を報告す る.

傿870-0948 大分市芳河原台 2-51

\section{材料および方法}

\section{1. 材料}

1995 年 7 月から 1998 年 10 月までに大分県内で採 取した温泉水 90 検体を検査材料とした。これらは，い ずれも飲用泉として新規に許可申請が予定された温泉水 である。

\section{2. 方法}

2.1 採水方法

細菌検查用試料の採水には $200 \mathrm{~m} l$ ポリエチレン製の 滅菌容器を用いた。採水前, 十分に排水した後, 採水し た。採水後は直ちに氷冷して冷蔵し，7時間以内に試験 室に搬入して，直ちに検查に供した。

\section{2 微生物学的衛生管理基準項目の検査}

一般細菌数, 大腸菌群および過マンガン酸カリウム消 費量 (以下, $\mathrm{KMnO}_{4}$ 消費量) の微生物学的衛生管理基準 3 項目は, 温泉利用基準一部改正通知の試験方法 ${ }^{2)}$ に 従って行った。

なお，細菌検査では，酸性（pH 4 以下）の検水は滅菌 した $2 N$ 炭酸ナトリウム溶液を加え, $\mathrm{pH}$ 試験紙（東洋ろ 紙(株)製ユニバーサル) で中性 (pH 7) になるように調 節した後, 検查に供した. 強アルカリ性を示した検水は なかった。

1）一般細菌数：検水原液および PBS (一) 溶液（日水 (株)製)で 10 倍に希釈した検水希釈液の各 $1 \mathrm{ml}$ をそれ ぞれ 2 枚ずっの滅菌シャーレ（テルモ(株)製）に採り, 標準寒天培地 (栄研化学(株)製) を用いて混釈し $37^{\circ} \mathrm{C}$ 
で 24 時間培養した。培養後の集落数を計測し，検水原 液の集落数が 300 未満ではその平均值を, 300 以上では 10 倍希釈した検水の集落数から算出した平均值を，一 般細菌数とした。

2) 大腸菌群：検水 $50 \mathrm{ml}$ をダーラム管入りの 3 倍濃 厚乳糖ブイヨン培地 (栄研化学(株)製) に接種し, $37^{\circ} \mathrm{C}$ で 48 時間培養後, ガスの発生を観察した。 ガスの発生 がみられたときは通知の試験方法 ${ }^{2)}$ に従って, ブリリア ントグリーン乳糖胆汁ブイヨン培地（同社製）を用いる 確定試験, さらにエオシンメチレンブルー寒天培地・標 準濃度の乳糖ブイヨン培地・普通寒天斜面培地（いずれ も同社製）を用いる完全試験を行って大腸菌群を判定し た.

3) $\mathrm{KMnO}_{4}$ 消費量: 検水 $100 \mathrm{~m} l$ を採り, 常温の硫酸 酸性で $0.01 \mathrm{~N}-\mathrm{KMnO}_{4}$ 溶液を滴下して, あらかじめ酸化 されやすい物質を酸化した後, 者沸による高温酸性下で $0.01 N-\mathrm{KMnO}_{4}$ 溶液および $0.01 N$-シュウ酸ナトリウム 溶液を用いて $\mathrm{KMnO}_{4}$ 消費量を湘定した。試薬はいずれ む和光純薬(株)製を使用した。

\section{3 理化学検査}

改定鉱泉分析法指針の試験方法 ${ }^{31} に$ 従って行った.

\section{4 微生物学的衛生管理基準}

飲用利用の微生物学的衛生管理基準 (2) (以下, 衛生管理 基準) では, 飲用温泉水の一般細菌数は 100 個 $/ \mathrm{m} l$ 以 下，大腸菌群は陰性， $\mathrm{KMnO}_{4}$ 消費量は $10 \mathrm{mg} / l$ 以下と 基準值が定められている．ただし， $\mathrm{KMnO}_{4}$ 消費量は必 要があれば検查すると規定されていて，鉄・硫黄・腐植 質を含む温泉水については $\mathrm{KMnO}_{4}$ 消費量は参考になら ない.

\section{結 果}

\section{1. 微生物学的衛生管理基準の検査結果}

飲用利用の衛生管理基準 ${ }^{2}$ で判定した検查結果を Table 1 に示した. 今回，検討した 90 検体中 30 検体， 33.3\% が衛生管理基準に不適合であった。この不適率は 細菌検查 2 項目による判定結果で，この 2 項目に必要時 の検査項目とされる $\mathrm{KMnO}_{4}$ 消費量の結果をあわせて判 定した不適合は 39 検体で，その不適率は $43.3 \%$ を示し た。

\section{項目別の不適では，一般細菌数が 23 検体 (25.6\%),}

Table 1. Hygienical results of the hot spring waters for drinking

\begin{tabular}{|c|c|c|}
\hline & $\begin{array}{l}\text { No. of } \\
\text { samples } \\
\text { tested }\end{array}$ & $\begin{array}{c}\text { No. of } \\
\text { positive } \\
\text { samples (\%) }\end{array}$ \\
\hline Bacteriological unconformity & 90 & $30(33.3)$ \\
\hline by Standard plate count & & $23(25.6)$ \\
\hline by Coliforms & & $9(10.0)$ \\
\hline by $E$. coli & & $1(1.1)$ \\
\hline $\begin{array}{l}\text { Unconformity by } \mathrm{KMnO}_{4} \\
\text { consumption }\end{array}$ & 90 & $12(13.3)$ \\
\hline
\end{tabular}

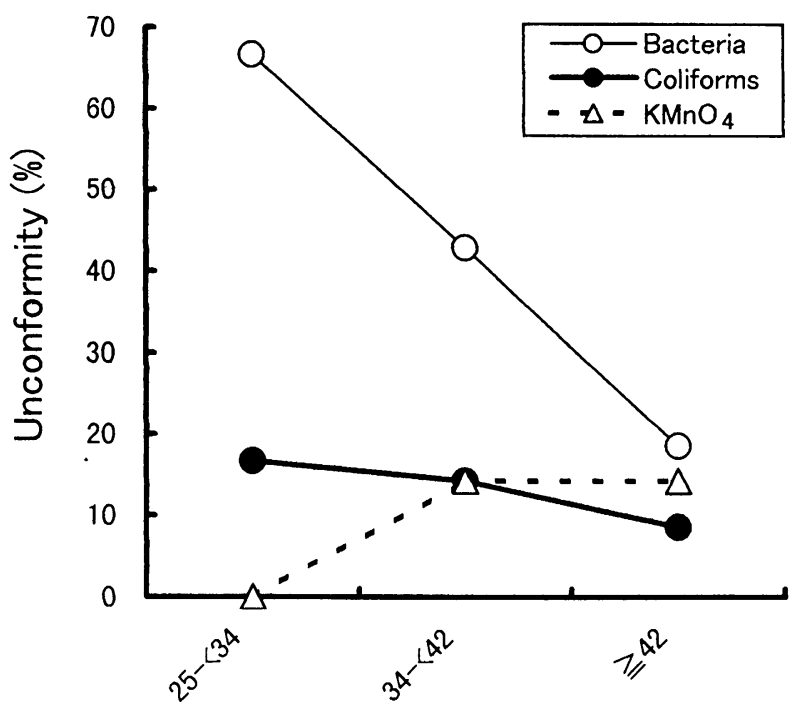

Temperature of hot springs $\left({ }^{\circ} \mathrm{C}\right)$

Fig. 1. Relationship between hygienical results and temperature of hot springs.

大腸菌群が 9 検体 (10.0\%), $\mathrm{KMnO}_{4}$ 消費量が 12 検体 (13.3\%) で，大腸菌群が不適の 1 検体からはE. coli が 検出された. また， 3 項目すべてによる不適は 1 検体 （1.1\%）で，一般細菌数と大腸菌群，一般細菌数之 $\mathrm{KMnO}_{4}$ 消費量, 大腸菌群と $\mathrm{KMnO}_{4}$ 消費量の各 2 項目 による不適がそれぞれ 1 検体 (1.1\%) ずっあった。

\section{2. 衛生管理基準項目と温泉分類との関係}

\section{1 泉温との関係}

鉱泉分析 ${ }^{3)}$ では, 温泉は泉温により低温泉 $\left(25 \sim 34^{\circ} \mathrm{C}\right.$ 未満), 温泉 (34 $42^{\circ} \mathrm{C}$ 未満), 高温泉 $\left(42^{\circ} \mathrm{C}\right.$ 以上) に 分類される. 今回検討した温泉水の泉温は $28.3 \sim 101^{\circ} \mathrm{C}$ の範囲にあったが, 泉温分類と衛生管理基準 3 項目の不 適率との関係を Fig. 1 に示した。

一般細菌数の不適率は，低温泉で $66.7 \%$ （6 検体中 4 検体が不適. 以下， $4 / 6$ と略記する), 温泉で $42.9 \%$ (6/ 14), 高温泉で 18.6\% (13/70) と泉温が低いほど高率で あった. その菌数の平均值士標準偏差 (S.D.) むそれぞれ $390 \pm 340$ 個 $/ \mathrm{ml}, 160 \pm 270$ 個 $/ \mathrm{ml}, 130 \pm 420$ 個 $/ \mathrm{ml}$ で, 泉温が低いほど高い值を示した。 また, 大腸菌群 の不適率はそれぞれ 16.7\% (1/6), 14.3\% (2/14), 8.6\% $(6 / 70)$ で，一般細菌数と同様に泉温が低いほど高かっ た. E. coli が検出された検体は低温泉であった。

一方, $\mathrm{KMnO}_{4}$ 消費量の不適率はそれぞれ $0 \%(0 / 6)$, 14.3\% (2/14)，14.3\% (10/70) で，また平均值士S.D.は それぞれ $3.2 \pm 1.7 \mathrm{mg} / l, 5.2 \pm 6.1 \mathrm{mg} / l, 6.9 \pm 12.4 \mathrm{mg} / l$ で，いずれも泉温が高いほど高い值を示した。

\section{$2.2 \mathrm{pH}$ との関係}

鉱泉は液性により酸性泉 ( $\mathrm{pH} 3$ 未満), 弱酸性泉 ( $\mathrm{pH}$ 3〜6 未満), 中性泉 ( $\mathrm{pH}$ 6 7.5 未満), 弱アルカリ性泉 (pH 7.5〜8.5 未満)，アルカリ性泉（ $\mathrm{pH} 8.5$ 以上）に分 
類される ${ }^{3)}$. 今回検討した温泉水の $\mathrm{pH}$ は $3.2 \sim 9.5$ の範 囲にあったが， $\mathrm{pH}$ と衛生管理基準項目の不適率との関 係を Fig. 2 に示した。

一般細菌数の不適率は, 弱酸性泉で $0 \%(0 / 2)$, 中性泉 で 30.0\% (9/30), 弱アルカリ性泉で 26.8\% (11/41)，ア ルカリ性泉で $17.6 \%$ (3/17) を示し，中性〜弱アルカリ 性域で高くなる傾向が認められた。その菌数の平均值士 S.D. は, 弱酸性泉が $2 \pm 3$ 個 $/ \mathrm{m} l$ に対して, 中性〜アル カリ性泉は $96 \pm 230 \sim 310 \pm 790$ 個 $/ \mathrm{ml}$ で, 弱酸性泉が 低い值を示した。また，大腸菌群の不適率は，中性泉扔 よび弱アルカリ性泉がそれぞれ $13.3 \%(4 / 30)$ および $12.2 \%(5 / 41)$ であるのに対し, 弱酸性泉とアルカリ性

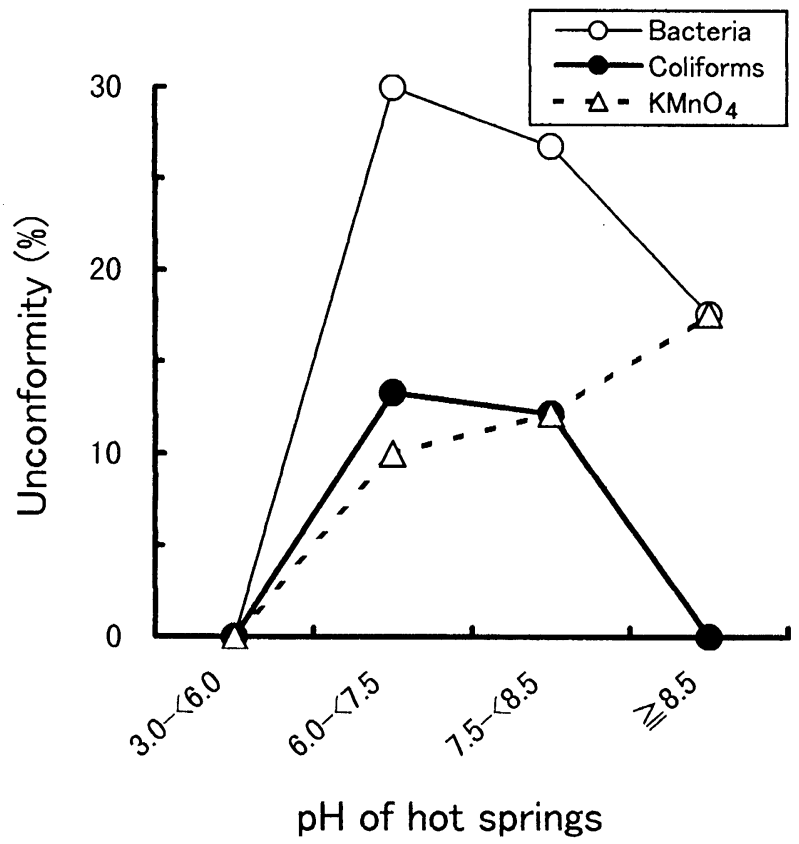

Fig. 2. Relationship between hygienical results and $\mathrm{pH}$.
泉はいずれあ不適がなく $(0 / 2$ と $0 / 17)$, 一般細菌数と 同様に中性〜弱アルカリ性域で高い不適率を示した。 $E$. coli の検出検体は中性泉であった.

一方, $\mathrm{KMnO}_{4}$ 消費量の不適率は弱酸性泉で $0 \%(0)$ 2), 中性泉で $10.0 \%(3 / 30)$, 弱アルカリ性泉で $12.2 \%$ (5/41)， アルカリ性泉で $17.6 \%(3 / 17)$ と pH が高いほ ど高率で， 平均值士S.D. もそれぞれ $2.7 \pm 2.2 \mathrm{mg} / l, 4.5$ $\pm 5.1 \mathrm{mg} / l, 4.6 \pm 4.8 \mathrm{mg} / l, 11.7 \pm 20.7 \mathrm{mg} / \mathrm{l}$ と $\mathrm{pH}$ の 上昇に従って高い值を示した。

\section{3 泉質との関係}

調查した 90 検体を療養泉の泉質 ${ }^{31}$ よって分類する と, 単純温泉が 47 検体 (52.2\%), 炭酸水素塩泉が 21 検 体 (23.3\%), 塩化物泉が 13 検体 (14.4\%)，アルカリ性単 純温泉が 7 検体 $(7.8 \%)$, 硫酸塩泉之硫化水素泉が各 1 検体 (1.1\%) であった．Fig. 3 には各泉質別の衛生管理 基準項目の不適率を示し, 調查した全検体の不適率と比 較した。

一般細菌数では全泉質の不適率 25.6\% (23/90) と比 べて, 炭酸水素塩泉の不適率が $33.3 \%(7 / 21)$ とやや高 かった。 しかし，その菌数の平均値士S.D. は，炭酸水素 塩泉 (21 検体) が $160 \pm 150$ 個 $/ \mathrm{ml}$ で, ほかの泉質検体 の $150 \pm 440$ 個 $/ \mathrm{ml}$ と比べて大差なかった。一方, アル カリ性単純温泉では大腸菌群による不適がなく $(0 / 7)$, ほかの泉質と比べて特徵的であった。

$\mathrm{KMnO}_{4}$ 消費量は，泉質との間で明らかな関係が認め られなかった。 また，硫酸塩泉之硫化水素泉の各 1 検体 は，衛生管理基準の 3 項目すべてに適合していた（図示 せず).

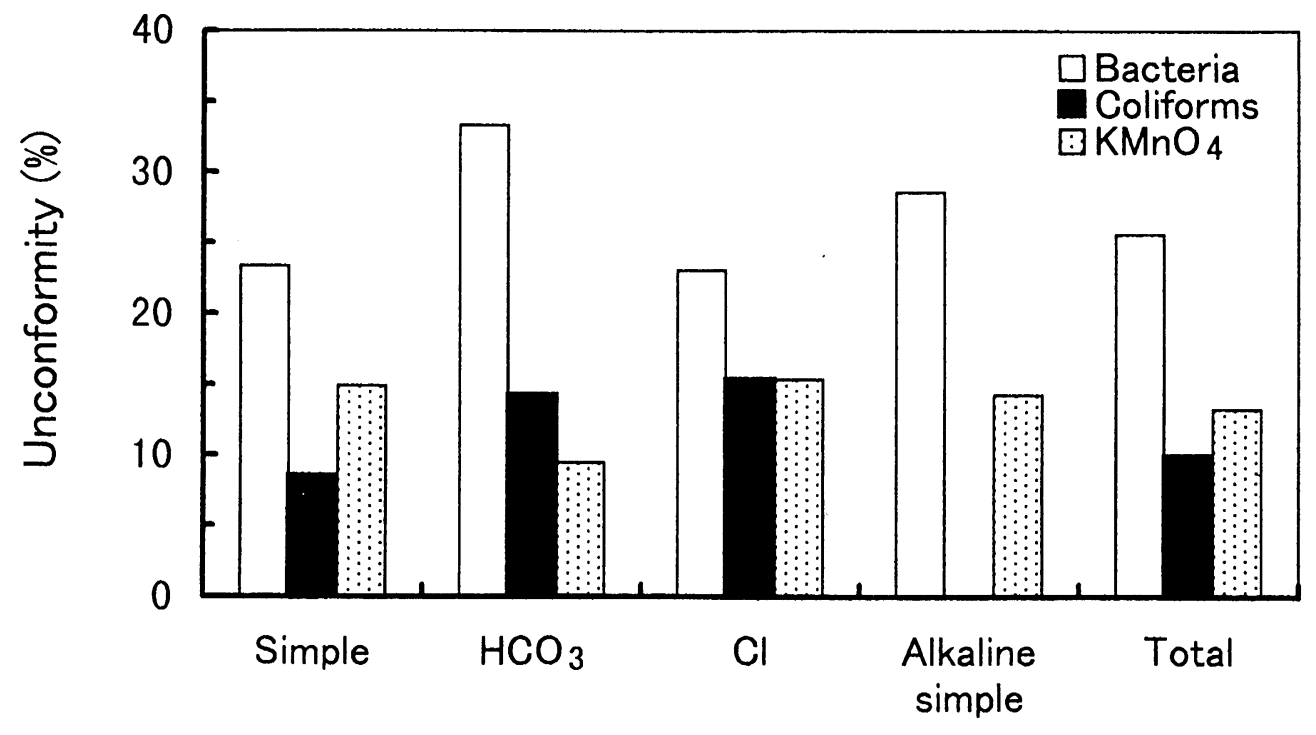

Type of springs

Fig. 3. Relationship between hygienical results and medicinal spring types. 
(A)Color

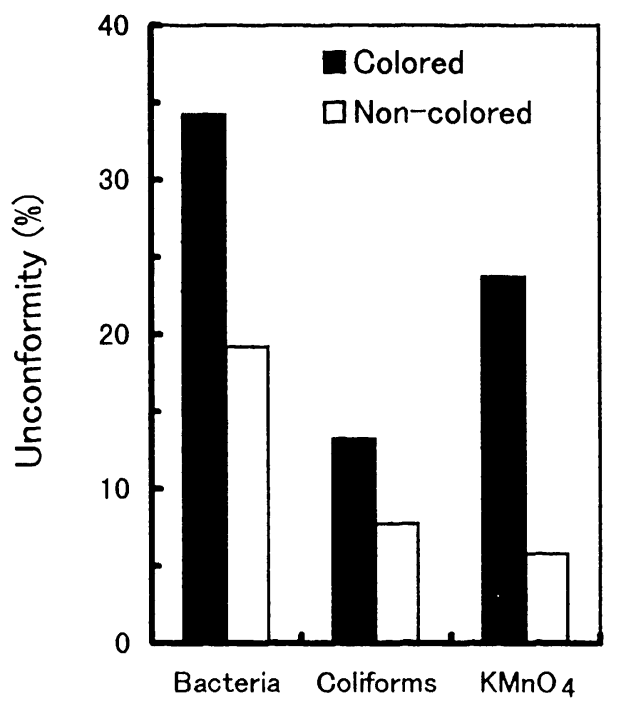

(B)Turbidity

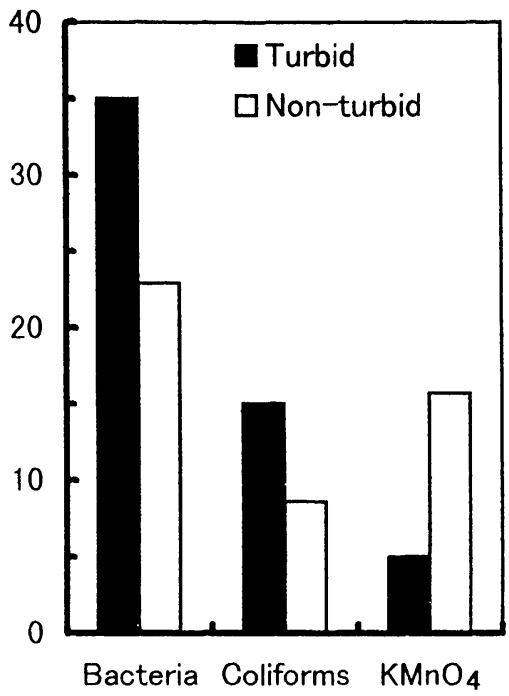

Fig. 4. Comparison of hygienical results in color or turbidity.

\section{3. 衛生管理基準項目と外観および飲用利用の理化学 成分との関係}

\section{1 外観との関係}

温泉の外観検査項目 ${ }^{3)}$ であ色および溞りと衛生管理 基準項月の不適率との関係を Fig. 4 に示した. 調查した 90 検体中着色が認められた 38 検体 $(42.2 \%)$ の不適率 は一般細菌数で 34.2\%(13/38)，大腸菌群で 13.2\%(5/ $38), \mathrm{KMnO}_{4}$ 消虫星で $23.7 \%$ (9/38) を示した。一方, 着 色のなかった 52 検体 (57.8\%) の不適率は，それぞれ 19.2\% (10/52), 7.7\% (4/52), 5.8\% (3/52) で, 各項目之 あ着色した温泉水の方が高かった。 そこで，着色の有無 別に検体の一般細菌数および $\mathrm{KMnO}_{4}$ 消費量の平均值士 S.D. を算出した. 各平均值は着色検体が $210 \pm 520$ 個/ $\mathrm{m} l$ および $8.4 \pm 15 \mathrm{mg} / l$, 無着色の検体が $110 \pm 310$ 個 $/ \mathrm{m} l$ および $4.0 \pm 4.6 \mathrm{mg} / l$ で，いずれも着色した温泉 水の方が高い值を示した．また，E. coli は着色検体から 検出された.

一方，濁りがみられた 20 検体 (22.2\%) の不適率は一 般細菌数で 35.0\% (7/20), 大腸菌群で 15.0\% (3/20), $\mathrm{KMnO}_{4}$ 消費量で $5.0 \%(1 / 20)$ を示したのに対し，濁り のなかった 70 検体 $(77.8 \%)$ の不適率はそれぞれ $22.9 \%$ (16/70), 8.6\% (6/70), 15.7\% (11/70)であった。混濁の 有無別に検体の一般細菌数および $\mathrm{KMnO}_{4}$ 消費量の平均 值土S.D. を比較すると, 混濁検体で $140 \pm 210$ 個/ $\mathrm{m} l$ および $3.9 \pm 2.8 \mathrm{mg} / l$, 濁りのない検体で $160 \pm 450$ 個 $/ \mathrm{m} l$ および $6.4 \pm 11 \mathrm{mg} / l$ であった。一般細菌数には 差が認められなかったが, $\mathrm{KMnO}_{4}$ 消費量は濁りのない 温泉水の方が高い値を示した. E. coli は混濁した温泉か ら検出された。

以上の結果から，着色や濁りのある温泉水は細菌検査 により，また混濁がなく着色した温泉水は $\mathrm{KMnO}_{4}$ 消費 量により，それぞれ衛生管理基準不適合になる可能性が 高いことが示峻された。

\section{2 飲用利用の化学成分との関係}

飲用利用基準 ${ }^{2}$ が適用される温泉水の化学成分は七 素, 銅, フッ素, 鉛, 水銀, 遊離炭酸の 6 成分で，これ ら成分の総摄取量は, 七素 $0.3 \mathrm{mg}$, 銅 $2 \mathrm{mg}$, フッ素 1.6 $\mathrm{mg}$, 鉛 $0.2 \mathrm{mg}$, 水銀 $0.002 \mathrm{mg}$ (以上, 大人の 1 日量), 遊離炭酸 $1,000 \mathrm{mg}$ (同 1 回量) を超えないように飲用 許容量が制限されている. 今回検討した温泉水 90 検体 中, 飲用量の制限が必要なものは 27 検体 (30.0\%) で あった，七素によるあのが $11.1 \%(10 / 90)$, フッ素によ るものが 22.2\% (20/90) で，うち 3.3\% (3/90) は両成分 による飲用制限を必要とした，Fig. 5 には，七素および フッ素と衛生管理基準項目の不適率との関係を示した。

七素により飲用量が制限された 10 検体の一般細菌数 による不適率は 20.0\%(2/10) で, 大腸菌群および $\mathrm{KMnO}_{4}$ 消費量による不適はなかった。一方，飲用制限 を受けなかった 80 検体の不適率はそれぞれ $26.3 \%$ (21/80), 11.3\% (9/80), 15.0\% (12/80) を示した。峏検 体別の不適率は一般細菌数では大差なかったが，大腸菌 群および $\mathrm{KMnO}_{4}$ 消費量では差が認められた。 そこで, 大腸菌群および $\mathrm{KMnO}_{4}$ 消費量と七素濃度との関連性に ついて検討した。

大腸菌群の不適 9 検体と適合 81 検体および $\mathrm{KMnO}_{4}$ 消費量の不適 12 検体と適合 78 検体について, 適・不 適の検体別にヒ素濃度の平均値士S.D. を比較したとこ ろ, 大腸菌群の不適検体で $0.089 \pm 0.112 \mathrm{mg} / l$, 適合検 体で $0.159 \pm 0.034 \mathrm{mg} / l$, また $\mathrm{KMnO}_{4}$ 消費量の不適検 体で $0.011 \pm 0.016 \mathrm{mg} / l$, 適合検体で $0.173 \pm 0.344$ $\mathrm{mg} / l$ と算定された。 七素濃度の平均値は，大腸菌群お よび $\mathrm{KMnO}_{4}$ 消費量とも適合した温泉水の方が高い值を 示した.

次に,フッ素により飲用制限を受けた 20 検体の一般 細菌数による不適率は $30.0 \%(6 / 20)$ で，大腸菌群によ る不適はなく, $\mathrm{KMnO}_{4}$ 消費量による不適率は $25.0 \%$ 
(A) $A_{S}$

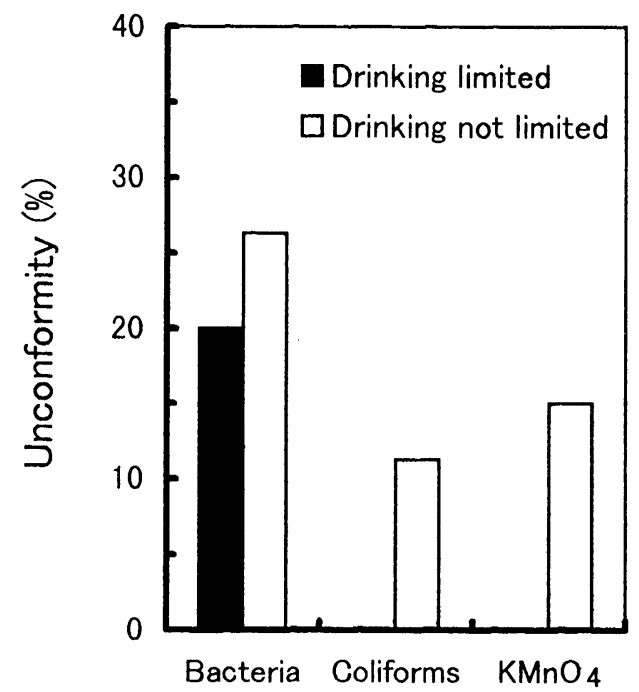

(B) $\mathrm{F}^{-}$

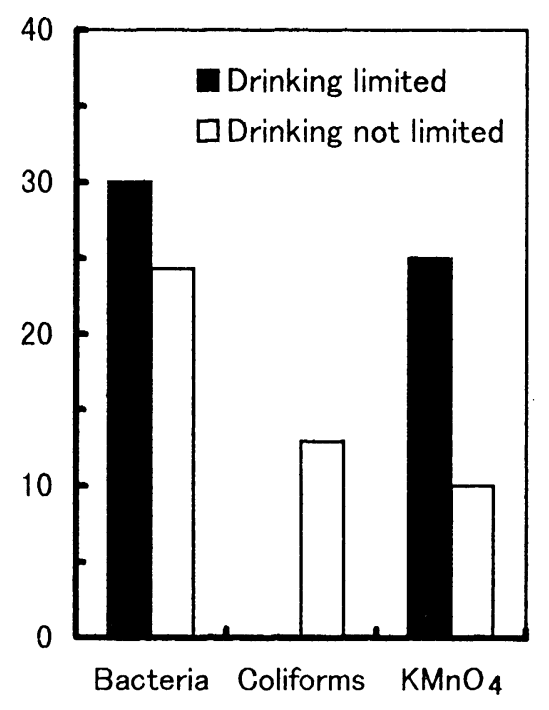

(5/20) であった。一方, 飲用制限を受けなかった 70 検 体の不適率は，それぞれ $24.3 \%(17 / 70), 12.9 \%$ (9/70), 10.0\% (7/70) を示した. 両検体別の不適率に明らかな 差が認められた大腸菌群および $\mathrm{KMnO}_{4}$ 消費量につい て，フッ素濃度との関連性を検討した，大腸菌群および $\mathrm{KMnO}_{4}$ 消費量の適・不適検体別にフッ素濃度の平均值 土S.D. を比較したところ，大腸菌群は不適検体で 0.262 $\pm 0.264 \mathrm{mg} / l$, 適合検体で $1.38 \pm 2.20 \mathrm{mg} / l$, また $\mathrm{KMnO}_{4}$ 消費量は不適検体で $2.30 \pm 2.89 \mathrm{mg} / l$, 適合検 体で $1.11 \pm 1.94 \mathrm{mg} / l$ と算定された. フッ素濃度の平均 值は，大腸菌群では適合した温泉水の方が， $\mathrm{KMnO}_{4}$ 消 費量では不適合の温泉水の方が，それぞれ高かった。な お，E. coli を検出した温泉は，七素およびフッ素による 飲用制限を必要としなかった。

以上の結果から，七素およびフッ素濃度が高い温泉水 では大腸菌群検出の可能性は低いが，フッ素濃度の高い 温泉水では $\mathrm{KMnO}_{4}$ 消費量により不適となる可能性が高 いことが示唆された。

\section{考察}

温泉水の飲用を許可していない四国など一部の地域を 除いて，近年全国的に飲用泉は増加の傾向にある ${ }^{9)}$. しか し, 温泉水の飲用は薬事法や食品衛生法の適用を受けな いため衛生上の問題が生じやすく, 環境庁自然保護局長 通知 ${ }^{2)}$ にっって, 飲用泉には微生物学的衛生管理のため の 3 項目基準と化学物質 6 成分の飲用利用基準が定め られている. 今回, 飲用泉許可の申請が予定された大分 県内温泉水 90 検体を対象に衛生状況を検討したが, 衛 生管理基準の不適率は $33.3 \%$ で極めて高かった，衛生 管理基準では, $\mathrm{KMnO}_{4}$ 消費量は必要があれば検査し, 鉄, 硫黄, 腐植質を含む温泉については参考にならない とされている.今回の結果はこれに従って判定したが,
$\mathrm{KMnO}_{4}$ 消費量も全検体について調查した. そこで, 細 菌検査の結果に $\mathrm{KMnO}_{4}$ 消費量の結果をあわせて判定し たところ, 衛生管理基準の不適率は 43.3\% で, さらに高 率を示した. また, 衛生管理基準の項目別の不適率は一 般細菌数が $25.6 \%$ で最も高く, 以下 $\mathrm{KMnO}_{4}$ 消費量が 13.3\%, 大腸菌群が $10.0 \%$ の順であった.

林ら ${ }^{1)}$ は静岡県内の飲用泉 21 検体を調べ, 検出率を一 般細菌数で $71.4 \%$, 大腸菌群で $9.5 \%$ と報告している.

また，飲用泉に鉱泉 26 検体と眝湯槽 7 検体を加えた合 計 54 検体での検出率は, 一般細菌数で $68.5 \%$, 大腸菌 群で 9.3\%, 粪便性大腸菌群で $5.6 \%$ という ${ }^{1)}$. 世取山ら は栃木県内の飲用対象でない鉱泉 222 検体 ${ }^{11)}$ を調べ, 衛 生管理基準の不適率が $7.7 \%$ (項目別の不適率は一般細

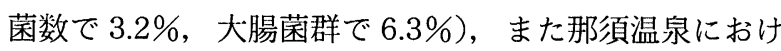
る同様の鉱泉 87 検体 ${ }^{12)}$ では不適率が $23.0 \%$ (一般細菌 数で 8.0\%，大腸菌群で 25.3\%）と報告している.これ らの報告と今回の調查結果を比較すると, 大腸菌群の不 適率は那須温泉の結果を除いてほぼ同程度と考えられ た。

一方, 一般細菌数の不適率は, 世取山らの報告の方が 著者らの結果より低く, 一般細菌数の不適率の違いが衛 生管理基準の不適率に反映していると考えられた。他 方, 林らの調査では, 一般細菌数は検出率で 68.5〜 $71.4 \%$ と報告されている. 今回の調查での一般細菌数の 検出率は $77.8 \%$ で, 林らの結果と大差なかった。一般細 菌数の不適率における世取山らとの相違は, 地域差のほ か河川水流入などによる環境污染，自然湧出泉など温泉 の形態や成因 ${ }^{111}$ などが原因として考えられる. 坂根ら ${ }^{10)}$ は, 静岡県内の鉱泉 4 力所（温泉と冷鉱泉の各 2 力所） を約 3 年間にわたり合計 12 回調べ，一般細菌数が温泉 ではそれぞれ $0 \sim 108$ 個 $/ \mathrm{m} l$ および $7 \sim 151$ 個 $/ \mathrm{m} l$, 冷鉱 泉ではそれぞれ 6〜 460 個 $/ \mathrm{m} l$ および $0 \sim 115$ 個 $/ \mathrm{ml}$ の 
範囲で変動したが，季節による影響はなかったと報告し ている，泉源によっては温泉水の一般細菌数は，かなり 大きな幅で変動していることが推察される.

今回の調查では衛生管理基準の複数項目による不適は 4 検体で, E. coli の検出む 1 検体に限られていた。 しか し，一般細菌数の不適率が極めて高かったことは，その すべてが二次污染によるあのとは考えにくいが，飲用泉 における衛生指標としての重要性を示唆している.

衛生管理基準項目之温泉分類との関係からは，細菌検 查項目による不適は泉温が低く, 中性〜弱アルカリ性 （pH 6 8.5 未満）を示す温泉に多い傾向がみられた．世 取山ら"11高泉温の温泉で不適率が高いことを報告して いるが，林ら ${ }^{11}$ は泉温と $\mathrm{pH}$ に関して著者らの結果と同 様の傾向を報告している，高い泉温や，強酸性または強 アルカリ性の温泉では, 二次的污染が起こりにくいこと が推察された。 また，七トに健康被害を及ぼす病原菌の 多くは中温菌であることから，泉温の高い温泉では例え 污染が起こってもその影響は少ないと考えられる. 高温 泉（泉温 $42^{\circ} \mathrm{C}$ 以上）以外に分類される温泉水の飲用に は, 特に注意が必要と思わ机た。療養泉の泉質分類では, アルカリ性単純温泉には大腸菌群による不適がなかっ た。これは同泉の $\mathrm{pH} 8.5$ 以上が原因していると考えら れた。林らはアルカリ性単純温泉で一般細菌数が少ない ことを報告しているが，今回の調查結果では同泉の 7 検 体中 2 検体（28.6\%）が一般細菌数により不適を示し た.

衛生管理基準項目と外観との関係では，着色や濁りの ある温泉で細菌検查による不適が多い傾向がみられた。

温泉ではしばしば腐植質による着色がみられる。特に大 分県内の温泉地は多くが山間部に点在して打り，また平 野部に分布する大分温泉でも深部 $800 \mathrm{~m}$ からの採湯で 腐植質の地層を通過するため, 温泉水の多くが着色して いる ${ }^{5,6,8)}$. しかし, 着色や混濁は二次的污染によっても 起こり両者を区別できないことから，着色や濁りのある 温泉水の飲用にはやはり注意が必要である。腐植質中の フミン酸はカシンベック病との関連性が指摘されて扔 り ${ }^{9)}$, この点からあ飲用は望ましくない.

衛生管理基準の参考項目である $\mathrm{KMnO}_{4}$ 消費量は，泉 温や $\mathrm{pH}$ が高い温泉ほよ゙，また着色した温泉の方が，い ずれも高い值を示す傾向がみられた．温泉水の着色は腐 植質によることが多く, $\mathrm{KMnO}_{4}$ 消費量が高值を示すの はこれに由来すると考えられた 6.8 . 飲用利用の化学成分 ではヒ素とフッ素により飲用量が制限を受けた。両成分 の濃度と大腸菌群および $\mathrm{KMnO}_{4}$ 消費量の間には関連性 か認められ, 大腸菌群を検出した温泉では両成分の平均 濃度が低かった. $\mathrm{KMnO}_{4}$ 消費量が不適な温泉では七素 の平均濃度が低く, フッ素の平均濃度が高い傾向がみら れた。 七素およびフッ素とあ生物学的には有害物質であ り,このことが大腸菌群の検出に関係している可能性が 考えられる.
なお，今回の調查で衛生管理基準に適合した温泉のう ち，実際に飲用泉の許可申請がなされ利用施設に登録さ れたのは約半数であった。

大分県は全国一の源泉数を有し, 特に別府市は単独の 温泉地としては源泉数, 涌出量とも全国第一位を誇って いる ${ }^{5,7)}$. 近年, 大分県内の飲用泉は新規の許可申請が増 え, 飲用施設数も急增している77. 他方, 飲用泉には年 1 回の細菌学的検查が義務付けられているが, 必ずしも遵 守されていない，今回の調查で大分県内に位置する飲用 泉の衛生上の問題点が明確になったことからここれまで 以上に微生物学的衛生管理を徹底していく必要がある。 また，今回は新規に飲用泉許可を申請するに際しての温 泉水を対象に衛生状況を検討したが, 既存の飲用泉施設 についても広範な調查が必要と考える.ささらに近年, 温 泉水を容器に入れて持ち帰るなどの事例が全国的に問題 となっているが, 飲用泉の適正な利用の指導と衛生知識 の啓発が，今後ますます重要と思われる.

\section{要 約}

1995 年 7 月から 1998 年 10 月にかけて大分県内で 採水された温泉 90 検体を用いて, 細菌学的検查を中心 に飲用泉の衛生状況を検討した。飲用利用の衛生管理基 準の細菌検查による不適率は $33.3 \%$ で,これに $\mathrm{KMnO}_{4}$ 消費量の結果をあわせたときの不適率は $43.3 \%$ であっ た. 項目別の不適率は一般細菌数で $25.6 \%$, 大腸菌群で $10.0 \%, \mathrm{KMnO}_{4}$ 消費量で $13.3 \%$ を示した.

衛生管理基準と温泉分類との関係加ら, 細菌検查によ る不適は泉温が低く, 中性〜弱アルカリ性の温泉に多い 傾向がみられた，泉質との関係では，アルカリ性単純温 泉には大腸菌群による不適がなかった。 外観との関係で は着色や混濁のある温泉で細菌検查による不適が多い傾 向がみられ，化学成分との関係では大腸菌群を検出した 温泉は七素およびフッ素の平均濃度が低かった。

他方, $\mathrm{KMnO}_{4}$ 消費量は泉温や $\mathrm{pH}$ が高い温泉ほど, また着色した温泉やフッ素濃度の高い温泉で, 高值を示 す傾向がみられた。衛生管理基準に適合した温泉のう ち, 実際に飲用泉の利用施設に登録されたのは約半数で あった。

本調查結果から, 大分県内の飲用泉施設について微生 物学的衛生管理をさらに獄底するとともに, 利用者には 飲用に当たっての適正な指導と衛生知識の啓発が重要と 考えられた。

\section{参考文献}

1) 林 道明, 秋山真人, 村上正博, 仁科徳啓, 杉枝正明, 塩 澤寛治, 橋本圭司, 海野忠市, 小澤邦雄, 大橋康弘：静岡 県内の温泉の細菌学的調查. 静岡県衛生環境センター報 告, 29, 89-93 (1986).

2) 環境庁: 温泉利用基準の一部改正について. 環自施第 438 号, 環境庁自然保護局施設整備課長通知, 平成元年 12 月 6 日 (1989). 
3）環境庁：鉱泉分析法指針（改定）, 環境庁自然保護局, 昭 和 53 年 5 月 (1978).

4) 真柴晃一, 浜本龍生, 鳥飼勝隆: 温泉水の誤嚥により発 症したと考えられるレジオネラ肺炎の 1 症例. 感染症学 雑誌，67(2), 163-166 (1993).

5）森山善蔵：大分県の地質と温泉. 温泉科学, $38(1,2)$, 43-51 (1988).

6) 野田俊郎：大分市内温泉の化学的特性. 大分県温泉調查 研究会報告, 32, 71-77 (1981).

7) 大分県：温泉の現況之保護及び利用対策. 平成 9 年環境 白書, 大分県生活環境部生活環境課, p. 45-50, 大分県, 大分 (1998).

8）大沢信二, 油佐悠紀：温泉の色について. 大分県温泉調 查研究会報告, 48, 41-49 (1998).

9) 酒井幸子: 群馬県の飲泉について. 温泉工学会誌, 25(1),
16-21 (1997).

10)坂根弓子, 海野忠市, 池谷静雄, 大滝高明, 渡辺 稔, 滝 本俊晴, 若沢秀幸, 仁科啓徳: 温泉水の季節変動調查（第 2 報). 静岡県衛生環境センター報告, $32, \quad 113-118$ (1989).

11）世取山 守, 大森亮一, 八島里美, 谷田部秀夫, 長門顕 子, 江連陽子, 鈴木秀夫：源泉の飲用のための細菌学的 研究. 温泉工学会誌, 24(1), 18-26 (1990).

12) 世取山 守, 長門顕子, 谷田部秀夫, 福田尚二, 岡田安 雄：那須温泉の地区特性について一泉温と化学成分の関 係, 成分等の濃度分布, 噴気泉, 飲用のための細菌污染 状況一. 杤木県衛生研究所報, 22, 57-68 (1992).

13）藪内英子, 王笠, 荒川迪生, 矢野郁也: 日本の温泉水 中の Legionella 属菌の分布. 感染症学雑誌, 68(4), 549551 (1994). 